\title{
Ostracods from the Upper Jurassic (Oxfordian-Tithonian) of southern Germany
}

\author{
U. SCHUDACK \& M. E. SCHUDACK
}

Institut für Paläontologie, Freie Universität Berlin, Malteserstr. 74-100, Haus D, 12249 Berlin, Germany (e-mail: schudack@zedat.fu-berlin.de).

\begin{abstract}
At present the ostracod faunas from the Upper Jurassic of southern Germany are incompletely known due to the absence of detailed studies. This preliminary systematic investigation has yielded 46 species from 25 genera, of which 23 species are left in open nomenclature, while 4 are new species: Bythoceratina (Praebythoceratina) danuvensis, Nemoceratina (Pariceratina) urlichsi, Pokornyopsis punctata and Quasihermanites spiralus. Diversity increases through the late Jurassic with 16 species in the Oxfordian, 19 species in the Kimmeridgian, and 23 species in the Tithonian. Endemism is lowest in the Oxfordian, while highest in the Kimmeridgian. J. Micropalaeontol. 19:(2) 97-112, December 2000.
\end{abstract}

\section{INTRODUCTION}

With few exceptions (e.g. Glashoff, 1964; Oertli, 1965), the ostracod faunas from the Upper Jurassic of southern Germany (Fig. 1) have not yet been studied in detail, possibly due to the rarity and often poorly preserved nature of the material. Ammonite faunas are, however, abundant and have been used for chronostratigraphy. This study looked at: (i) the pattern and diversification of ostracod biogeography, (ii) the possible correlation of ammonite biozones from southern Germany with ostracod biozones in northern Germany; and (iii) contributions to the palaeoclimatic history of the late Jurassic in Central Europe. For these investigations, which are based on a larger set of data including species which have been reported by other authors, see Schudack \& Schudack (1997), Schudack (1999) and a short summary in the conclusions in this paper.
Here, a provisional inventory and systematic investigation of the ostracod fauna, systematic descriptions of four new species, several recombinations of taxa, some comments on other taxonomical problems, and the stratigraphical ranges in southern Germany are given, as well as figures of the species. Another new species, Palaeocytheridea groissi, has already been described in Schudack (1997).

\section{MATERIAL}

The material studied in this paper has been gathered from a number of sources. Samples from the Franconian Jurassic (Fig. 1) have been provided by Dr Schairer (Munich) and Professor Groiss (Erlangen). A total of 113 samples from 25 sections (summarized to 18 areas in Fig. 2) have yielded the ostracods

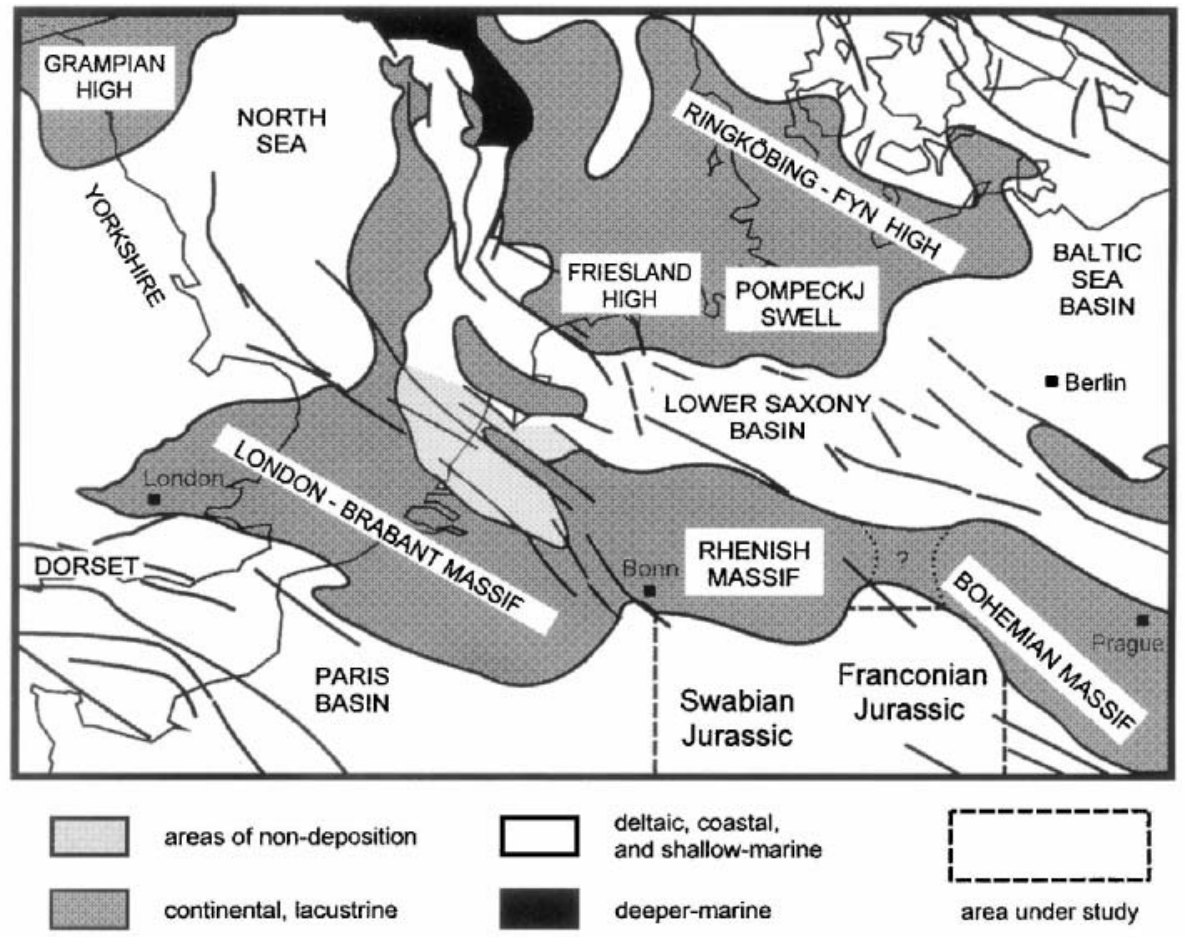

Fig. 1. Palaeogeography of the Kimmeridigan and Tithonian in Central Europe (redrawn after Ziegler, 1990) and position of the study area (Swabian and Franconian Jurassic) between the Central European Swell (Rhenish and Bohemian massifs) to the north and the Tethys to the south. 


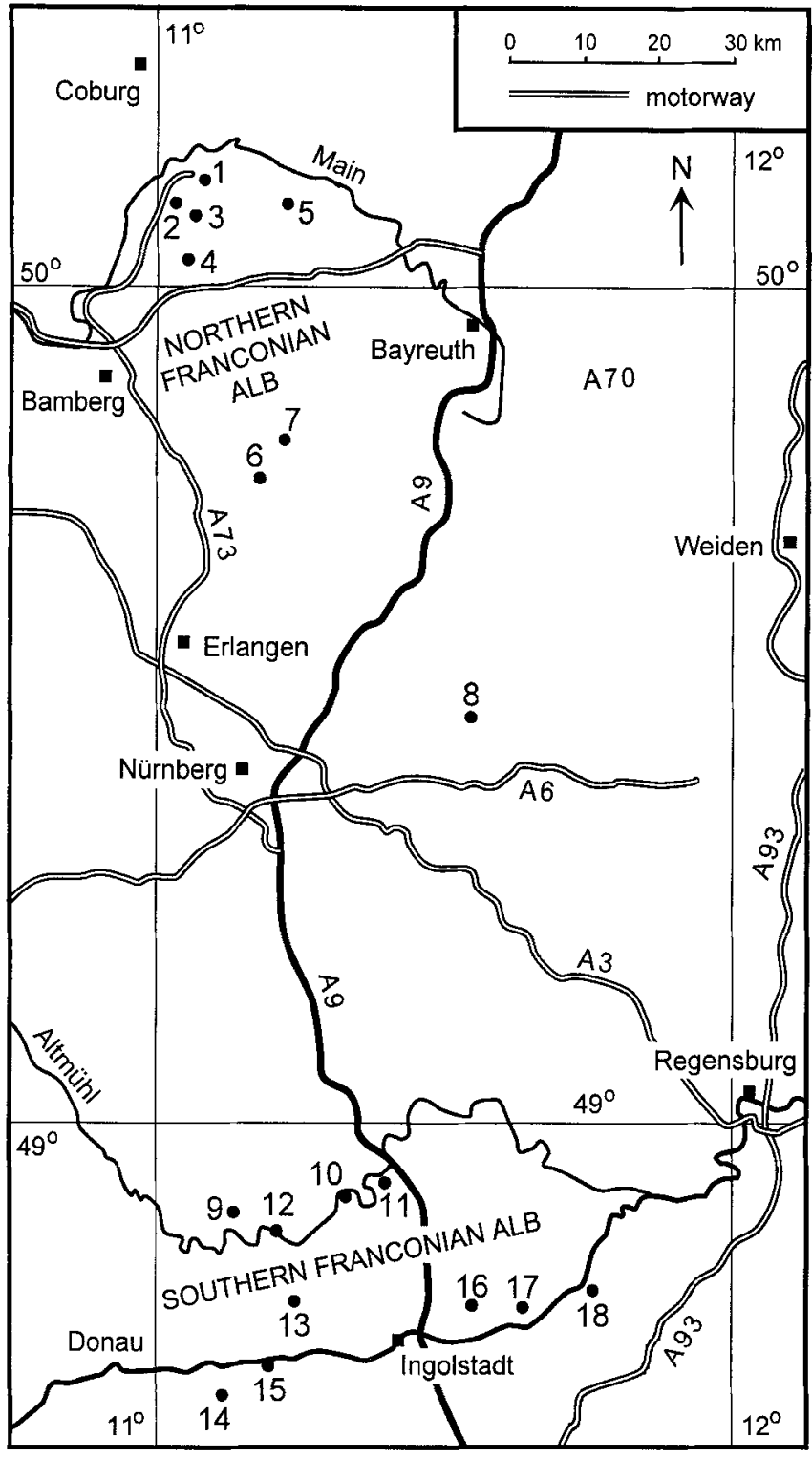

Fig. 2. Position of sampled localities in the Franconian Jurassic (see Fig. 1). 1, SE Lichtenfels (Schwabthal, Lahmer Steige, Attendorfer Steige, Dörrwasserlos); 2, area near Staffelstein (Spitzberg, Staffelberg); 3, Uetzing; 4, Dornig/Oberküps; 5, Weismain; 6, Ebermannstadt/Rüssenbach; 7, Schauertal N Streitberg; 8, Hartmannshof; 9, Sappenfeld; 10 , Pfalzpaint; 11, Kipfenberg; 12, Eichstätt; 13, Untermöckenlohe; 14, Unterhausen; 15, Neuburg/Donau; 16, Demling; 17, Ober/Unterhartheim; 18, Haderfleck (Neustadt/Donau).

considered in this paper. Their stratigraphical ranges are from the Oxfordian into the Middle Tithonian (Fig. 3). Most of the material from the Swabian Jurassic (Fig. 1) comprises picked samples donated by Dr Urlichs (Stuttgart) and from our own field work in the southernmost part of the Swabian Alb mountains. Here, a total of 25 samples from 9 sections (summarized to 8 areas in Fig. 4), have yielded ostracods, ranging from the Oxfordian into the early Tithonian (Fig. 5). If not noted otherwise, the material is housed at the Institute of
Paleontology of the Free University of Berlin.

\section{OSTRACODS FROM THE UPPER JURASSIC OF SOUTHERN GERMANY}

This preliminary account of the Upper Jurassic ostracods from southern Germany has identified 46 species from 25 genera, of which 23 species are left in open nomenclature. Their stratigraphical ranges in southern Germany are shown in Fig. 6. A general increase in diversity through the Upper Jurassic is evident, with 16 species occuring in the Oxfordian, 19 species in the Kimmeridgian and 23 species in the Tithonian. The relative age of each of the ostracod-bearing layers has been determined on the basis of the well-established ammonite biozonation which has been studied in southern Germany since the last century (for summaries and lists of older literature see Zeiss (1977), Ziegler (1977), Dietl \& Schweigert (1995), or Schweigert \& Callomon (1997)).

All species are figured on Plates 1-5, whereas in the systematics section only those taxa presented as a new species or requiring more discussion have been described.

\section{SYSTEMATIC DESCRIPTIONS OF NEW SPECIES \\ Order Podocopida Müller, 1894 \\ Suborder Platycopina Sars, 1866 \\ Family Cytherellidae Sars, 1866 \\ Genus Cytherelloidea Alexander, 1929}

'Formenkreis' of Cytherelloidea weberi/paraweberi/tripartita (P1. 1, figs 4-7)

Within this 'Formenkreis', two groups of species are distinguished: Cytherelloidea gr. weberi Steghaus, 1951 and $C$. gr. tripartita Glashoff, 1964. The weberi group includes the individuals usually described as C. weberi or C. paraweberi, two species of which are considered to be synonymous (Schudack, 1994). In this group, the peripheral rib extends subparallel to the valve margins, dorsally it may be slightly undulated, while anteroventrally and/or anterodorsally it may be interrupted. The valve is either smooth or reticulated. A median rib and two knob-like protuberances occur immediately in front of the posterior margin in the female carapaces.

Cytherelloidea gr. tripartita Glashoff, 1964 includes individuals with the dorsal part of the rib subdividing into three oblique fragments, situated staggered in succession. It also includes those forms, like the Czech species 'Cytherelloidea aff. mandelstami Pokorny, 1973' in which the dorsal rib turns, with a pronounced angle, at half length of the carapace to the anterior, where it runs a distance under the frontal rib. Many of these ostracods posses a subdorsal rib (sensu Pokorny), which is situated in case of reduction of the posterior part of the dorsal rib instead of the third fragment of the interrupted dorsal rib. Species figured and described as 'weberi' or 'paraweberi' by Oertli (1959, pl. 2, figs 28, 29), Donze (1960, pl. 1, fig. 5) and Depèche (1985, pl. 34, fig. 2) also belong to this 'Formenkreis'.

All individuals recorded from southern Germany belong to Cytherelloidea gr. tripartita.

Suborder Podocopina Sars, 1866 Superfamily Cytheracea Baird, 1850 


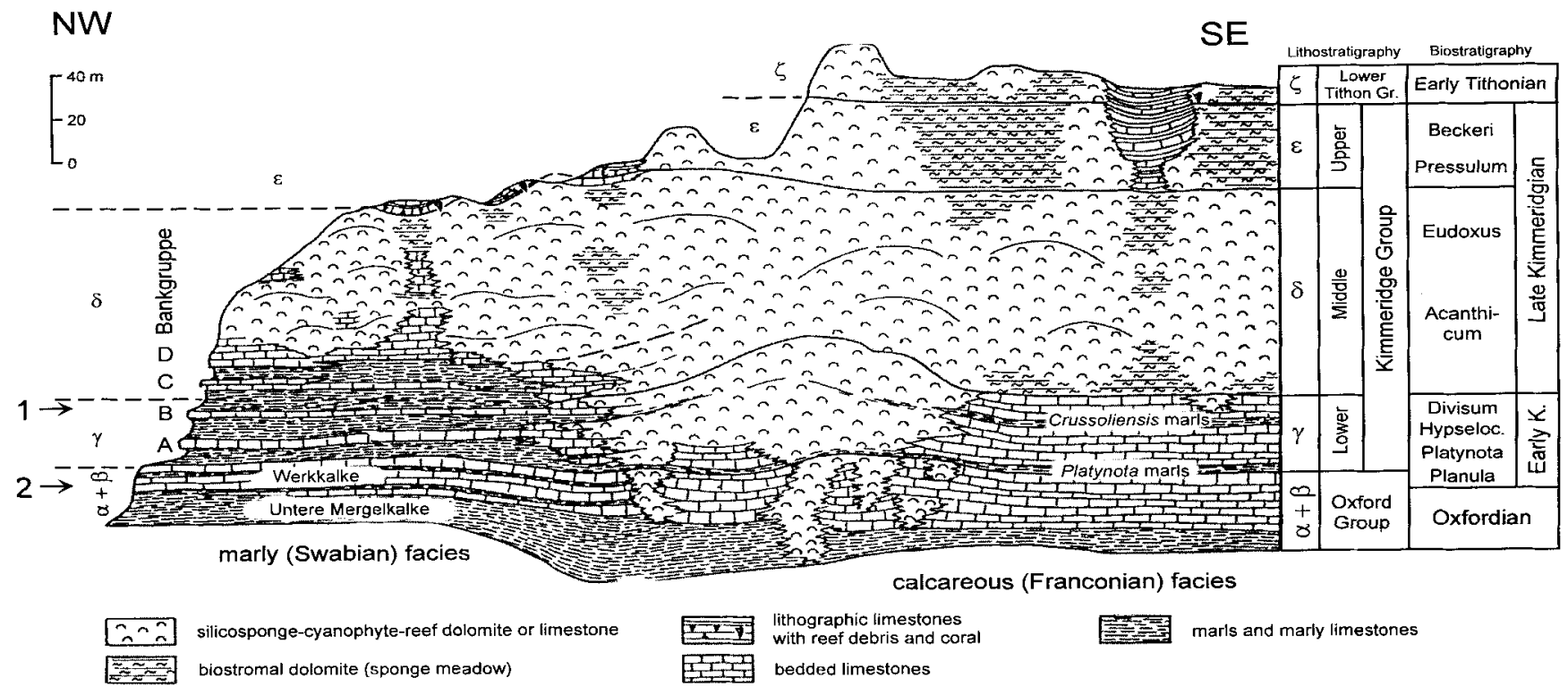

Fig. 3. Generalized litho- and biostratigraphy of the northern Franconian Upper Jurassic (Fig. 2), redrawn and modified after Zeiss (1977) and Meyer \& Schmidt-Kaler (1996); position of the Oxfordian/Kimmeridgian boundary after Schweigert \& Callomon (1997), with stratigraphical positions of type horizons of Bythoceratina (Praebythoceratina) danuvensis n. sp. (1) and Pokornyopsis punctata n. sp. (2). On the southern Franconian Alb (Fig. 2), a slightly different Jurassic facies reaches up into the Middle Tithonian (Neuburger Bankkalke).

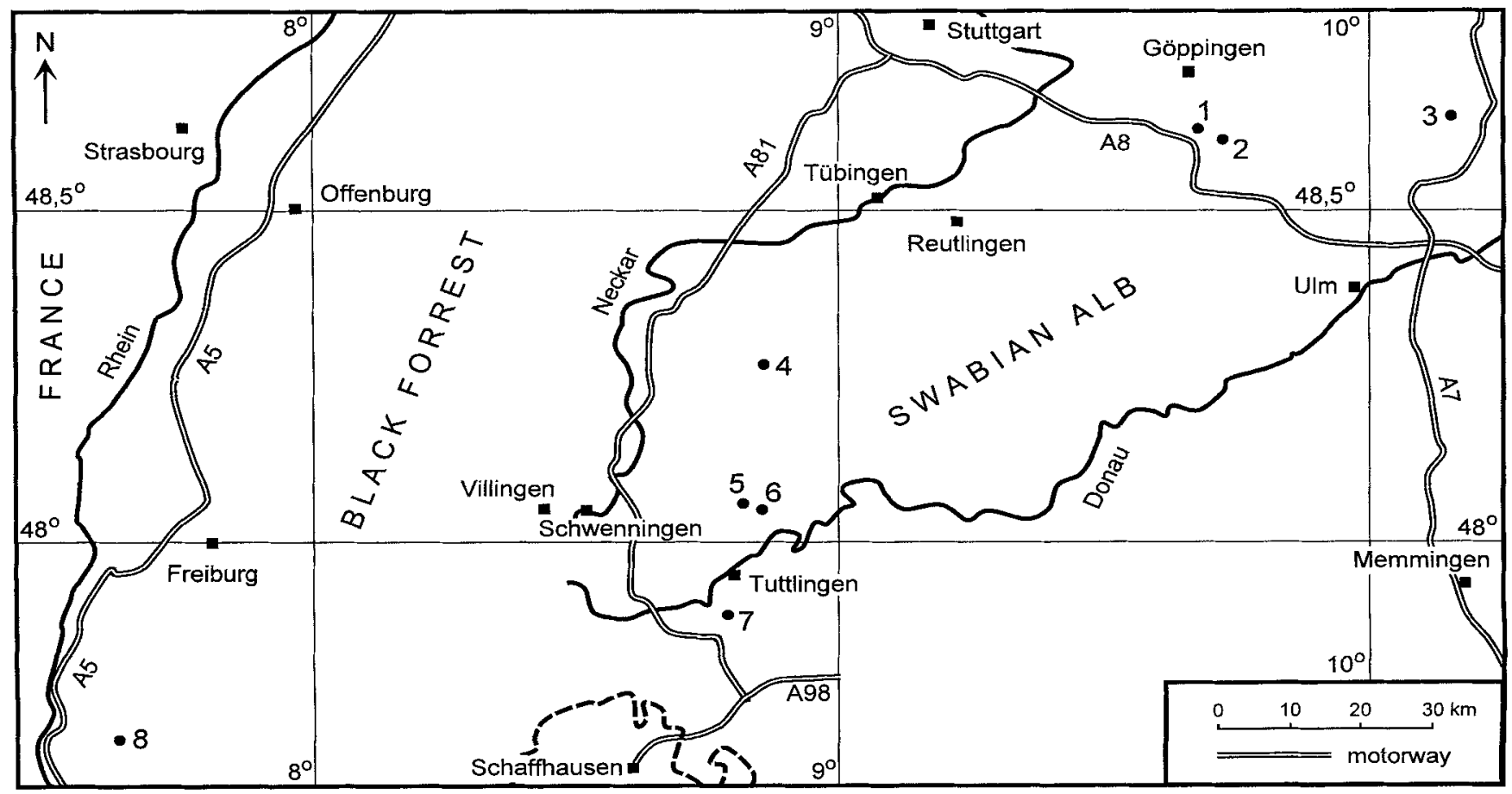

Fig. 4. Position of sampled localities in the Swabian Jurassic (see Fig.1). 1, Auendorf; 2, Reichenbach im Täle; 3, Bolheim; 4, Irrenberg and Lochenpass near Balingen; 5, Aggenhausen W Mahlstetten; 6, Mahlstetten; 7, railway cutting north of Engen; 8, Kandern. 


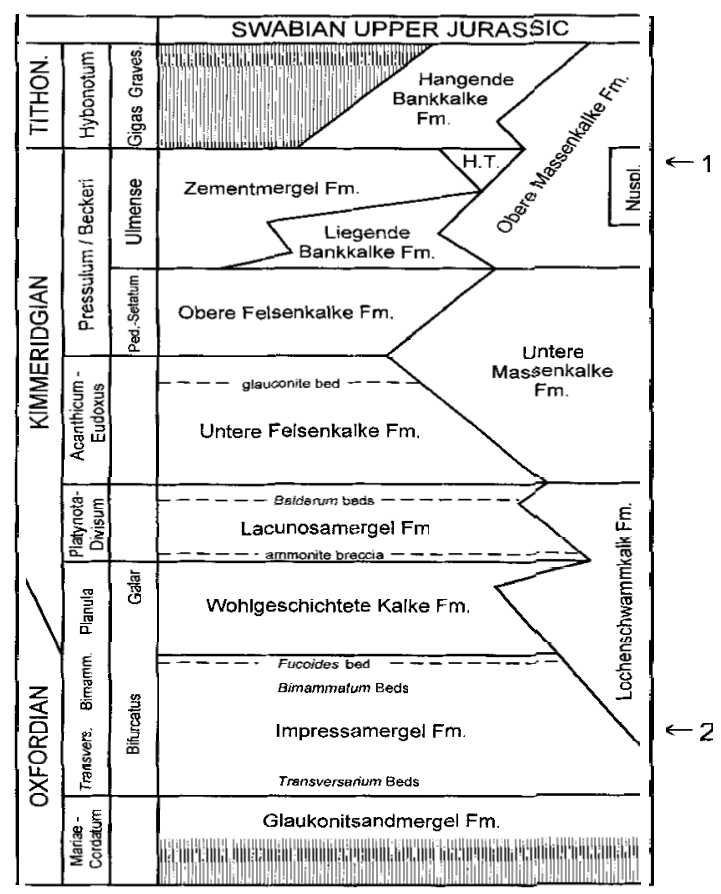

Fig. 5. Generalized litho- and biostratigraphy of the Swabian Upper Jurassic (redrawn after Dietl \& Schweigert, 1995) with stratigraphical positions of type horizons of Quasihermanites spiralus n. sp. (1) and Nemoceratina (Pariceratina) urlichsi n. sp. (2). Abbrevations: HT, Hattinger Trümmerkalke Facies; Nuspl., Nusplinger Plattenkalke Facies.

Family Bythocytheridae Sars, 1926

Subfamily Bythocytherinae Sars, 1926

Tribus Bythoceratini Gründel \& Kozur, 1972

Genus Bythoceratina Hornibrook, 1952

Subgenus Praebythoceratina Gründel \& Kozur, 1972
Bythoceratina (Praehythoceratina) danuvensis n. sp. (Pl. 1, figs 14-16)

cf. 1973 Bythoceratina n. sp A Pokorny: 95, pl. 12, fig. 4 ? 1975 Monoceratina $\mathrm{sp}$. B Bate: 180, pl. 2, fig. 3.

1987 Bythoceratina (Praebythoceratina) sp. A Lord et al.: 591, fig. $8 / 1$.

1987 Monoceratina of. sp. B Bate, 1975; Rosenfeld et al: 239, pl. 1, fig. 13 .

Derivation of name. From the largest river (Donau/Danube) in Southern Germany where the species is frequent in many regions.

Diagnosis. A species of the genus Bythoceratina (subgenus Praebythoceratina) with the following distinctive features: carapace elongate, dorsal and ventral margins subparallel. Median furrow in most cases is limited by a marginal rib, often with knobs at its anterior border. Valve surface carries pentagonal pits, arranged in a characteristical matter.

Types. Holotype, left valve (Plate 1, fig. 14). Paratypes, about 50 specimens. Staatliches Museum für Naturkunde Stuttgart, Inventory-Nr. 75106/1.

Locality \& horizon. Dornig, SE Staffelstein, northern Franconian Alb, Bavaria, TK 25 sheet 5932 Uetzing (Fig. 2). Sample Groiss 181. Lower Kimmeridgian, Malm gamma, $1.3 \mathrm{~m}$ above 'Bankgruppe B' (Fig. 3).

Description. The carapaces are elongated-rhomboid, the dorsal and ventral borders are subparallel. The ventral margin is sinuous, posteroventral margin convex, extending into an inclined, slightly elongated caudal process, situated posterodorsally. The anterior margin is broadly rounded, similar to the posterior margin, and possesses a marked selvage. The lateral surfaces are unevenly inflated, overlapping the ventral margin centrally and with a prominent spine postero-ventrally. The median furrow is broad and low, sometimes smaller and deeper and in most cases rampart-like, with one knob immediately above mid-height and another one situated diagonally across in

\section{Explanation of Plate 1}

Figs 1-2. Cytherella woltersdorf Oertli, 1959: 1, Malm delta, Kimmeridgian; sample Groiss 132; Heilstätte E Schwabthal, SE Lichtenfels; left valve, length $0.51 \mathrm{~mm} ; 2$, lamberti Zone, henrici Subzone, uppermost Callovian, Kandern, leg; Dietl, left valve from inside, length $0>66 \mathrm{~mm}$. InventoryNr.75121/1 Staatliches Museum für Naturkunde Stuttgart. Fig. 3. Cytherella sp., lower Kimmeridgian, sample Groiss 126, Heilstätte E Schwabthal, SE Lichtenfels, right valve, length $0.41 \mathrm{~mm}$. Fig. 4. Cytherelloidea sp. A. Oertli, 1957, Lower Tithonian, sample Groiss 491, Haderfleck, Blatt Neustadt/Donau, right valve, length $0.66 \mathrm{~mm}$. Figs 5-6. Cytherelloidea ex gr. tripartita Glashoff, 1964, Hattinger Trümmerkalke, Upper Kimmeridgian, sample SD 22, Talmühle, $2 \mathrm{~km}$ north of Engen, railway cutting on the Tuttlingen/Singen line: 5, left valve, length $0.54 \mathrm{~mm} ; \mathbf{6}$, left valve, length $0.56 \mathrm{~mm}$. Fig. 7. Cytherelloidea cf. varicosa Donze, 1960, Malm Zeta 2b, Upper Solnhofener Schichten, Lower Tithonian, sample Groiss 724b, Quarry X, Schöpfel/Hofstetten, S Pfalzpaint, near Eichstätt, right valve, length $0.50 \mathrm{~mm}$. Figs 8-9. Bairdia sp. Schwamm-Mergel, bimammatum Zone, Upper Oxfordian, Schauertal near Streitberg, near Forchheim (Oberfranken), leg, Urlichs: 8, right valve from inside, length $0.89 \mathrm{~mm}$, Inventory-Nr. 75113/1 Staatliches Museum für Naturkunde Stuttgart; 9, right valve, length $0.89 \mathrm{~mm}$, Inventory-Nr. $75113 / 2 \mathrm{Staatliches} \mathrm{Museum} \mathrm{für}$ Naturkunde Stuttgart. Figs 10-11. Paracypris sp.: 10, Mörnsheimer Schichten, Lower Tithonian, sample Groiss 106, quarry in the City Forest, west of Neuburg/Donau, left valve, length $0.45 \mathrm{~mm}$; 11, Malm Zeta 2b, Upper Solnhofener Schichten, Lower Tithonian, sample Groiss 749, quarry north of Demling, right valve, length $0.46 \mathrm{~mm}$. Figs 12-13. Pontocyprella suprajurassica Oertli, 1959. Impressa marls, bifurcatus Subzone, Upper Oxfordian, crest at Irrenberg near Balingen, leg, Urlichs 1.5.1967: 12, right valve, length $0.57 \mathrm{~mm}$, inventory-Nr. $75108 / 2$ Staatliches Museum für Naturkunde Stuttgart; 13, right valve, length $0.57 \mathrm{~mm}$, inventory-Nr. $75108 / 1$ Staatliches Museum für Naturkunde Stuttgart. Figs 14-16. Bythoceratina (Praebvthoceratina) danuvensis $\mathrm{n}$. sp.: 14, holotype, Malm gamma, Lower Kimmeridgian, sample Groiss 181, Dornig, SE Staffelstein, left valve, length $0.50 \mathrm{~mm} ; 15$, Malm gamma, Lower Kimmeridgian, sample Groiss 183, Dornig, SE Staffelstein, left valve, length $0.52 \mathrm{~mm}$; 16, Impressa marls, bifurcatus Zone, Upper Oxfordian, crest at Irrenberg near Balingen, leg, Urlichs 1.5.1967, dorsal view, distance between the ends of the spines $0.59 \mathrm{~mm}$, inventory-Nr. 75106/1 Staatliches Museum für Naturkunde Stuttgart. Figs 17-18. Bythoceratina (Praebythoceratina) stimulea (Schwager, 1866): 17, bifurcatus Zone, Upper Oxfordian, Reichenbach im Täle, Coll. K. Feifel, 1947, left valve, length $0.57 \mathrm{~mm}$, inventory-Nr. 75117 Staatliches Museum für Naturkunde Stuttgart; 18, Malm gamma, Lower Kimmeridgian, S Weismain, sample Groiss 177, dorsal view, distance between the ends of the spines $0.48 \mathrm{~mm}$. Figs 19-21. Nemoceratina (Pariceratina) urlichsi n. sp. 19, holotype, bifurcatus Zone, Upper Oxfordian, Reichenbach im Täle, Coll. K. Feifel, 1947, left valve, length $0.63 \mathrm{~mm}$, inventory-Nr. 75115/1 Staatliches Museum für Naturkunde Stuttgart; 20, bifurcatus Zone, Upper Oxfordian. Reichenbach im Täle, Coll. K. Feifel, 1947. Right valve, length $0.66 \mathrm{~mm}$, inventory-Nr. 75115/2 Staatliches Museum für Naturkunde Stuttgart; 21, Malm delta, Kimmeridgian, sample Groiss 138, Oberküps, S Lichtenfels, left valve, length $0.53 \mathrm{~mm}$. 


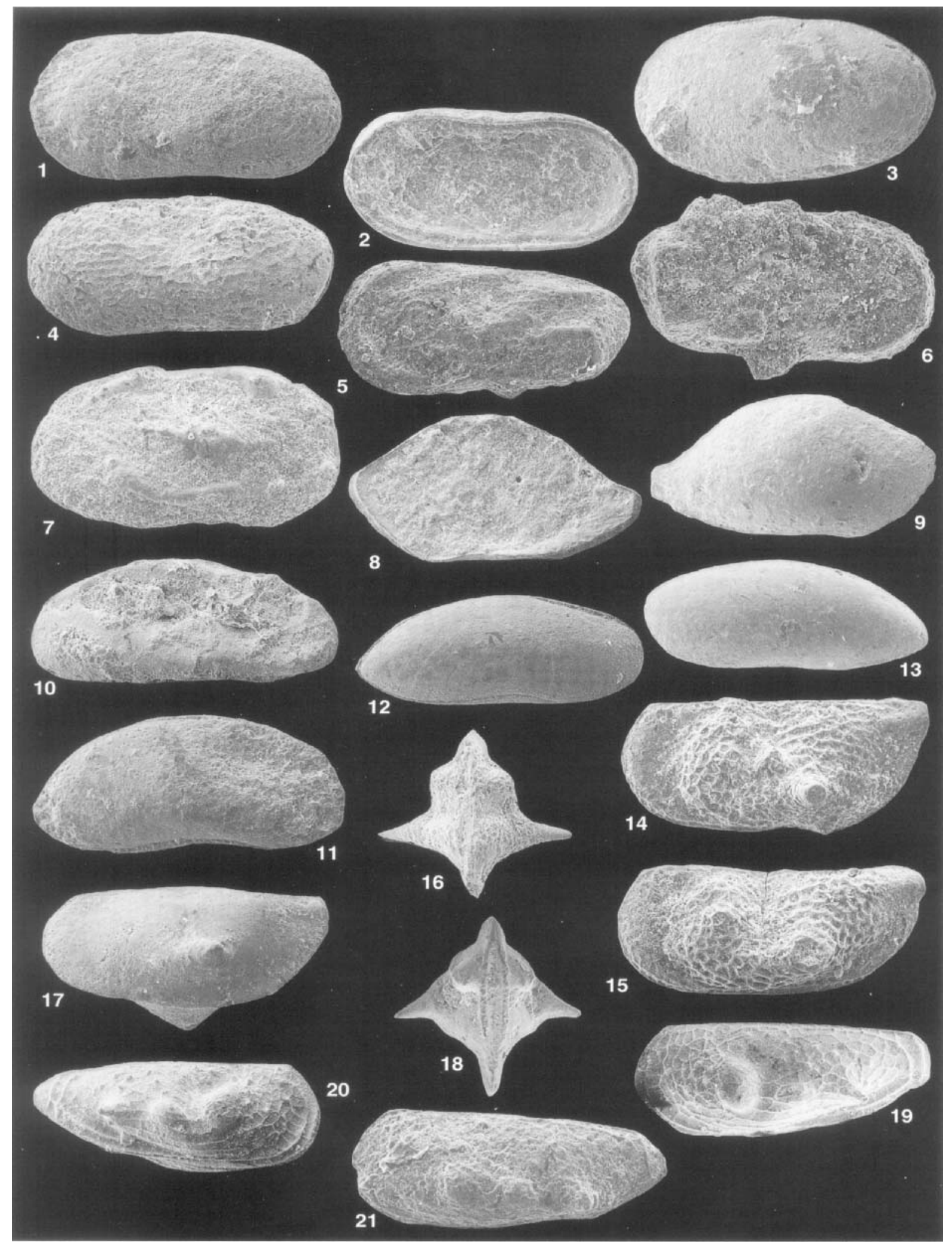




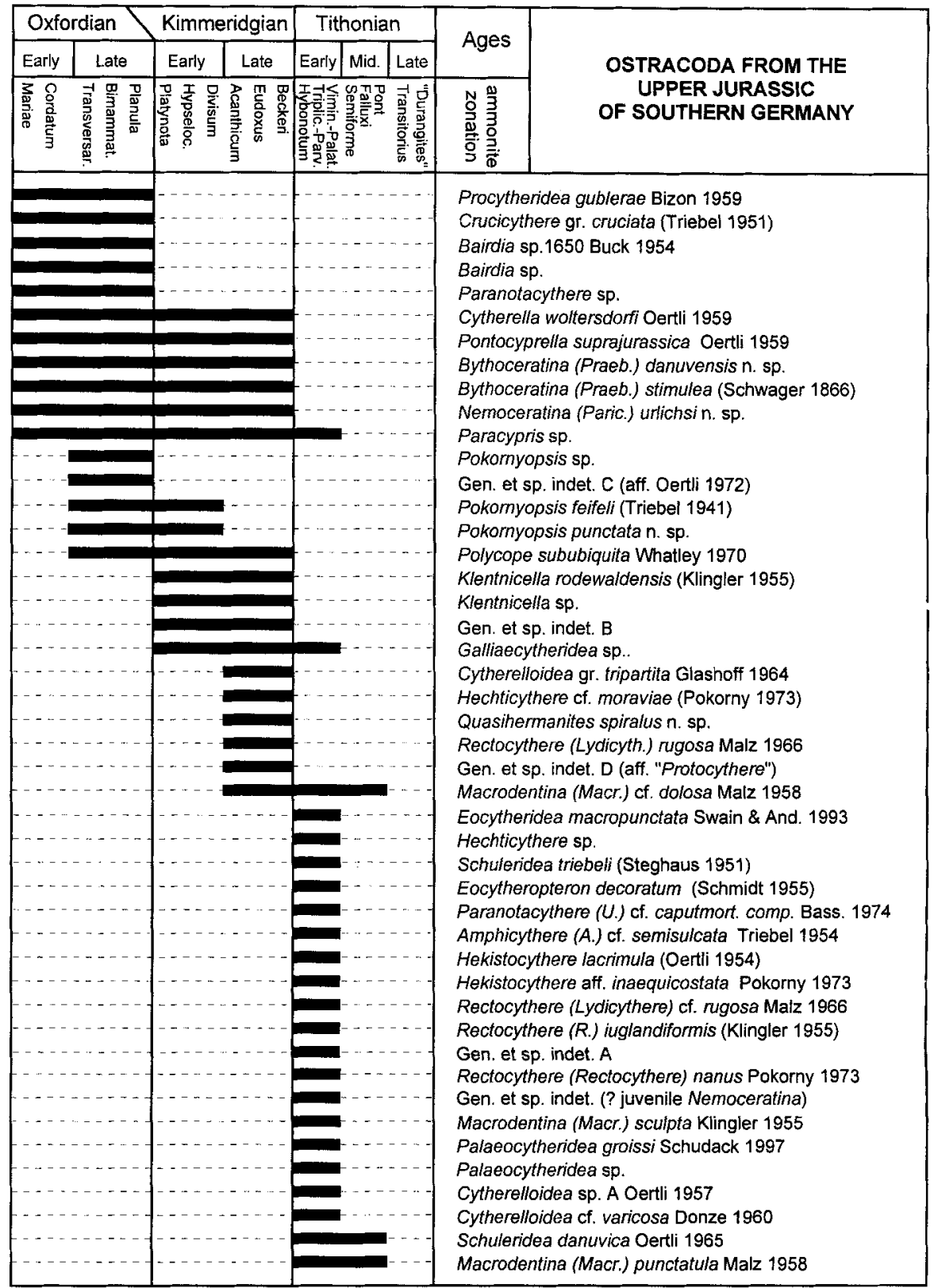

Fig. 6. Stratigraphical ranges of ostracode species in the Upper Jurassic of southern Germany. The ammonite zonation given here is a composite for Southern Germany after Zeiss (1977), Dietl \& Schweigert, (1995) and Schweigert \& Callomon (1997). All species listed here are figured on Plates I-5, whereas in the section on 'systematics' only those taxa which are new species or which require more discussion have been described.

front of it. Occasionally, these knobs are very small. The valve surfaces are covered with pentagonal pits, arranged in rows along the marginal surface and near the ventral margin. They extend around the root of the spine and the median furrow and reflect the sculpture of the valves. In dorsal view, the carapaces are arrow-shaped, the anterior and posterior margins being pronounced keel-like. Eye-tubercles and lateral spines are well pronounced. Internal details not observed.

Dimensions. Length $0.50-0.57 \mathrm{~mm}$, height $0.23-0.26 \mathrm{~mm}$.
Occurrence. In southern Germany this taxon occurs in the Oxfordian and Kimmeridgian. Pokorny (1973) described this species from the Kimmeridgian of the lower Klentnice Formation in Southern Moravia (see Schudack \& Schudack, 1997 concerning the revised age of this formation). Bate (1975) records this species from the Middle Callovian of Tanzania, Lord et al. (1987) from the autissiodorensis Zone (Kimmeridgian) of the Volga Basin and Rosenfeld et al. (1987) from the Oxfordian Kidod Formation of Israel. 
Remarks. The species shows strong similarities to Bythoceratina (Praebythoceratina) scrobiculata (Triebel \& Bartenstein, 1938), from which it is probably derived. Both species are distinguished by the inflation of the valve selvages, the form of the caudal process, and the reticulate surface ornamentation.

Genus Nemoceratina Gründel \& Kozur in Kozur, 1971 Subgenus Pariceratina Gründel \& Kozur, 1972

Nemoceratina (Pariceratina) urlichsi $\mathrm{n} . \mathrm{sp}$. (Pl. 1, figs 19-21)

Derivation of name. In honour of Dr M. Urlichs, Museum of Natural History, Stuttgart, Germany, who kindly made the material available.

Diagnosis. A species of the genus Nemoceratina (subgenus Pariceratina) with the following characteristics. Keel-like prominences are seen on the anterior and posterior margins. The valve surfaces are reticulate, covered with small pointed spines located on the angles of the sculptural meshes. There is no anterodorsal lobe and there are three knobs parallel to the ventral border.

Types. Holotype, left valve (Plate 1, fig. 19). From Coll. K. Feifel, 1947. Paratypes, 5 specimens. Staatliches Museum für Naturkunde Stuttgart, Inventory-Nr. 75115/1.

Locality \& horizon. Reichenbach im Täle, Swabian Alb, BadenWürttemberg, TK 25 sheet 7324 Geislingen an der Steige West (Fig. 4). Upper Oxfordian, bifurcatus subzone, Impressamergel (Fig. 5).

Description. In lateral view, the carapaces are trapezoidally elongated, with their greatest height at the anterior cardinal angle. The dorsal margin is straight and only slightly inclined to the pronounced posterior cardinal angle. The posterior margin is rounded subtriangular, with a large caudal process situated above mid-height. The transition to the ventral border is rounded, the latter being overlapped by the slight inflation of the lateral surfaces. The anterior margin is broadly rounded. The valve surface comprises a network of fine meshes, which join in the marginal areas to form small ribs. Finely pointed spines or papillae are irregularly distributed at the angles of these meshes. Anterior and posterior borders possess keel-like pronounces without any sculpture. In front of the caudal process, a distinct furrow is developed, underlining the posterior margin more strongly. Immediately above the median part of the ventral border, three knobs are situated in a subparallel line. The anterior knob, which lies at the base of a small sulcus, is the largest. Both the anterior and median knob are smooth, while the posterior knob terminates into a small spine.

Dimensions. Length $0.52-0.64 \mathrm{~mm}$, height $0.21-0.27 \mathrm{~mm}$. Occurrence. Southern Germany, Oxfordian to Kimmeridgian. Remarks. Nemoceratina (Pariceratina) urlichsi n. sp. is considered to be closely related to Nemoceratina $(P$.) sp. Depèche (1985: 135, pl. 31/14), but differs in the development of the ventral knobs and the posterior end. The anterior margin is rounded and narrower, and the reticulation is less evident. Further research is necessary to show ancestoral relationships with the Bathonian specimens from Normandy.

Family Cytherettidae Triebel, 1952

Subfamily Palaeocytherideinae Ljubimova, 1955
Tribus Hechticytherini Gründel, 1974

Genus Hechticythere Gründel, 1974

\section{Hechticythere cf. moraviae (Pokorny, 1973)}

(P1. 2, fig. 2)

Remarks. Pokorny (1973) described this species as part of the subgenus Valendocythere, which was regarded as a genus by Gründel (1974a,b). However, the only criterion for Valendocythere would be the bulb-like thickening of the ventral rib posteriorly. Neither a decomposition of the lateral ribs into single lobes nor a reduction of them, nor a development of a median lobe or a reduction of the dorsal rib is observed in our material and so the species is regarded as belonging to the genus Hechticythere Gründel, 1974.

Family Cytheruridae Müller, 1894

Subfamily Cytherurinae Müller, 1894

Genus Paranotacythere Bassiouni, 1974

Subgenus Unicosta Bassiouni, 1974

Paranotacythere (Unicosta) cf. caputmortuum compactum Bassiouni, 1974

(Pl. 3, figs 3-4)

1974 Paranotacythere (Unicosta) caputmortuum compactum Bassiouni: pl. 13, figs 11-12.

Occurrence. Lower Tithonian of southern Germany. Couches à gigas, Lower Tithonian of France.

Remarks. Only two poorly preserved valves have been recovered. Both specimens are placed into $P$. caputmortuum $s$. $l$. because of the following characters. The presence of nodes anteroventrally and on the lateral surfaces posteriorly behind the median furrow are distinctive as is the ala-like projection of the ventral rib posteriorly. The valves are closely related to the species described by Bassiouni (1974: pl. 13, figs 11-12) as $P$. caputmortuum cf. compactum from the Ile d'Oléron (France).

Family Progonocytheridae Sylvester-Bradley, 1948 Genus Hekistocythere Bate, 1969

\section{Hekistocythere lacrimula (Oertli, 1959)}

(P1. 3, fig. 9)

1959 Cytherura ? lacrimula Oertli: 29--30, pl. 4, figs 107-111.

1963 Cytherura ? lacrimula Oertli; Oertli: pl. 38, fig. 1c.

1990 Metacytheropteron elegans Oertli; Zihrul: 78, p1. 4, fig. 41. 1995 'Cytherura' lacrimula Oertli, 1959; Weiss: $149-150$, pl. 8, figs $3-4$

Occurrence. Lower Tithonian of southern Germany, Upper Oxfordian to Lower Kimmeridgian of Switzerland and northwestern Germany

Remarks. The species, which was questionably assigned to Cytherura Sars, 1866 by Oertli (1959), is now placed into Hekistocythere Bate, 1969 because of the identical lophodont hinge, the general outline, and the corresponding marginal structures.

\section{Hekistocythere aff. inaequicosta Pokorny, 1973}

(Pl. 3, figs 10-11)

Occurrence. Lower Tithonian of southern Germany.

Remarks. Only a few specimens have been recovered. The taxon 


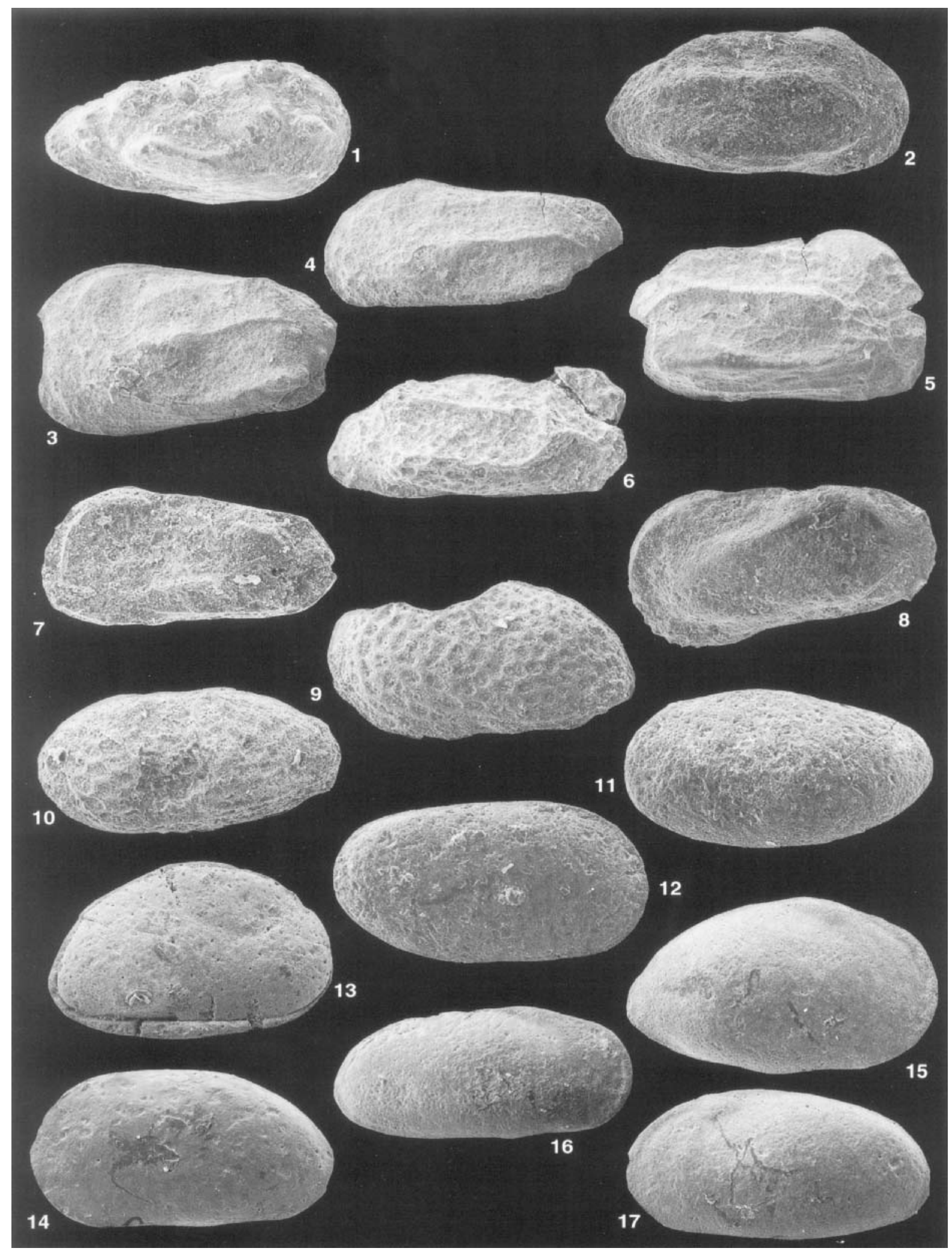


possesses irregular broad crests and intercalated reticulate pits. The specimens are considered to be closely related to Hekistocythere inaequicosta Pokorny, 1973 from the Kimmeridgian of southern Moravia which were re-identified by Witte \& Lissenberg (1994) in the Upper Kimmeridgian/Lower Portlandian of the North Sea Graben of the Netherlands. However, the southern German species differ from the taxon in having a more differentiated pattern of ornamentation.

\section{Genus Quasihermanites Gründel, 1964}

\section{Quasihermanites spiralus n. sp.}

$$
\text { (Pl. 4, figs 6-7) }
$$

Derivation of name. From the spiral arrangement of the sculptural ribs.

Diagnosis. A species of the genus Quasihermanites Gründel, 1964 , in which the ribs are arranged in a rectangular-formed spiral.

Types. Holotype, left valve (Pl. 4, fig. 7). Paratypes, 3 specimens. Institut für Paläontologie FU Berlin, Inventory Nr. MT 1997-1. Locality \& horizon. Talmühle $2 \mathrm{~km}$ north of Engen, on the Tuttlingen-Singen railway, southern Swabian Alb, BadenWürttemberg, TK 25 sheet 8118 Engen (Fig. 4). Sample SD 22 of our 1995 field campaign. Marl at the base of Hattinger Trümmerkalke Member (base of outcrop), uppermost Kimmeridgian (uppermost pressulum/beckeri Zone, Fig. 5).

Description. Lateral view of the carapaces subrectangular, with the greatest height at the well-rounded anterior cardinal angle. Elongated eye-tubercle developed beneath the angle. The dorsal and ventral margins are straight and converge towards the posterior. Ventral margin is overlapped by the lateral surfaces in its median part. Posterior margin narrowly rounded, somewhat keel-like pronounced from the lateral surfaces like the more thickened anterior one. The sculpture comprises a series of ribs arranged in a rectangular-formed spiral. The dorsal rib, which is characteristic of the genus, commences beneath the eye-tubercle, extending above the dorsal margin mid-length, with its apex situated in the posterior third. In the posterior third of the valve the dorsal rib extends vertically, joining the ventral rib at $1 / 4$ carapace height. This transition is variable and not always absolutely evident. The ventral rib is convex and joins the anterior rib, which extends subparallel to the anterior margin to the eye spot, arcuatedly. The eye spot is linked with the dorsal rib by a small crest. At the origin of the dorsal rib, or immediately beneath it, a slightly undulating horizontal median rib occurs situated at about 2/3 carapace-height. Between the lateral ribs, the valve surface is reticulate. In dorsal view, the carapaces are rectangular, the anterior and posterior margins projected keel-like, the dorsal rim is evident. No internal details are observed, due to the material only comprising carapaces. This would be interesting with regard to the statement of Pokorny (1973), whose species Quasihermanites bicarinatus moravicus differs from $Q$. bicarinatus Gründel, 1964 and $Q$. caistorensis (Kaye, 1965) only by the terminal elements of the merodont hinge. These are crenulated in the Moravian form and smooth in the two younger species from the Middle Hauterivian to Lower Barremian of England and Lower Hauterivian of Germany.

Dimensions. Length $0.46-0.48 \mathrm{~mm}$, height $0.26-0.29 \mathrm{~mm}$.

Remarks. Quasihermanites spiralus n. sp. differs from the closely related species $Q$. bicarinatus Gründel, 1964, Q. caistorensis (Kaye, 1965) and Q. bicarinatus moravicus Pokorny, 1973 by the spiral arrangement of its lateral ribs.

Family Trachyleberididae Sylvester-Bradley, 1948

Subfamily Neurocytherinae Gründel, 1975

Genus Crucicythere Malz, 1975

Crucicythere gr. cruciata (Triebel, 1951)

(Pl. 4, figs 14-17)

Occurrence. Uppermost Callovian to Oxfordian of southern Germany.

Remarks. The specimens occurring in southern Germany can be assigned to Crucicythere cruciata (Triebel, 1951), but classification to one of the subspecies of Lutze (1960) is difficult. A close relationship to C. c. intermedia (Lutze, 1960) is evident, but in this subspecies the vertical ribs extend straight upwards from the median rib, whereas they are much more oblique in the south German specimens. C. c. oxfordiana (Lutze, 1960), is the most similar subspecies, but lacks the vertical ribs in the posterior intercostal field. In addition, it has reduced the frontal rib in its

\section{Explanation of Plate 2}

Fig. 1. Gen et sp. indet, ? larval stage of Nemoceratina sp., Lower Mörnsheimer Schichten, Lower Tithonian, sample Groiss 37, Oberhartheim near Vohburg a. d. Donau. right valve, length $0.27 \mathrm{~mm}$. Fig. 2. Hechticythere cf. moraviae (Pokorny, 1973), Hattinger Trümmerkalke, Upper Kimmeridgian, sample SD 25, Talmühle, $2 \mathrm{~km}$ east of Engen, railway cutting on the Tuttlingen/Singen line, right valve, length $0.72 \mathrm{~mm}$. Figs 3-5. Hechticythere sp., Lower Mörnsheimer Schichten, Lower Tithonian, sample Groiss 37, Oberhartheim near Vohburg/Donau: 3, left valve, length $0.46 \mathrm{~mm} ; \mathbf{4}$, left valve, length $0.45 \mathrm{~mm} ; 5$, left valve, length $0.44 \mathrm{~mm}$. Fig. 6. Klentnicella rodewaldensis (Klingler, 55), Malm ?delta, Kimmeridgian, sample Groiss 172, east of Staffelstein, right valve, length $0.42 \mathrm{~mm}$. Figs 7-8. Klentnicella sp. 7, Malm gamma 3, Lower Kimmeridgian, sample SD 15, road cutting, I km ESE of Mahlstätten; left valve, length $0.62 \mathrm{~mm} .8$, Klentnicella sp., Hattinger Trümmerkalke, Upper Kimmeridgian, sample SD 27 , Talmühle, $2 \mathrm{~km}$ east of Engen, railway cutting on the Tuttlingen/Singen line, left valve, length $0.72 \mathrm{~mm}$. Fig. 9. Eocytheridea macropunctata Swain \& Anderson, 1993, lower Mörnsheimer Schichten, Lower Tithonian, sample Groiss 37, Oberhartheim near Vohburg/Donau, left valve, length 0.41 mm. Fig. 10. Eocytheridea of. macropunctata Swain \& Anderson, 1993, Malm Zeta 2b, Upper Solnhofener Schichten, Lower Tithonian, sample Groiss 724d, quarry X, Schöpfel/Hofstetten, south of Pfalzpaint near Eichstätt, left valve, length $0.44 \mathrm{~mm}$. Figs 11-12 Galliaecytheridea sp., Malm delta, Kimmeridgian: 11, sample Groiss 136, NW Dörnwasserlos, S Lichtenfels, left valve, length $0.45 \mathrm{~mm}$. 12, sample Groiss 138, Treppenberg near Oberküps, S Lichtenfels, right valve, length $0.45 \mathrm{~mm}$. Figs 13-14. Schuleridea danuvica Oertli, 1965, Malm zeta 2, Lower Tithonian, sample Groiss 496, Haderfleck, Blatt Neustadt/Donau: 13, right valve, length $0.69 \mathrm{~mm} ; \mathbf{1 4}$, right valve, length $0.68 \mathrm{~mm}$;. Figs 15-18. Schuleridea triebeli (Steghaus, 1951): 15-16, Upper Solnhofener Schichten, Malm Zeta 2b, Lower Tithonian, sample Groiss 724b, quarry X, Schöpfel/Hofstetten south of Pfalzpaint near Eichstätt; 15, right valve of a female, length $0.48 \mathrm{~mm} ; 16$, right valve of a male, length $0.48 \mathrm{~mm}$; 17, Lower Mörnsheimer Schichten, Malm zeta 3 , Lower Tithonian, sample Groiss 730, quarry Imberg near Pfalzpaint east of Eichstätt, right valve of a male, length $0.61 \mathrm{~mm}$; 18 , Malm Zeta $2 \mathrm{~b}$, Upper Solnhofener Schichten, Lower Tithonian, sample Groiss 734, quarry X. Schöpfel/Hofstetten south of Pfalzpaint near Eichstätt, left valve of a male, length $0.56 \mathrm{~mm}$. 


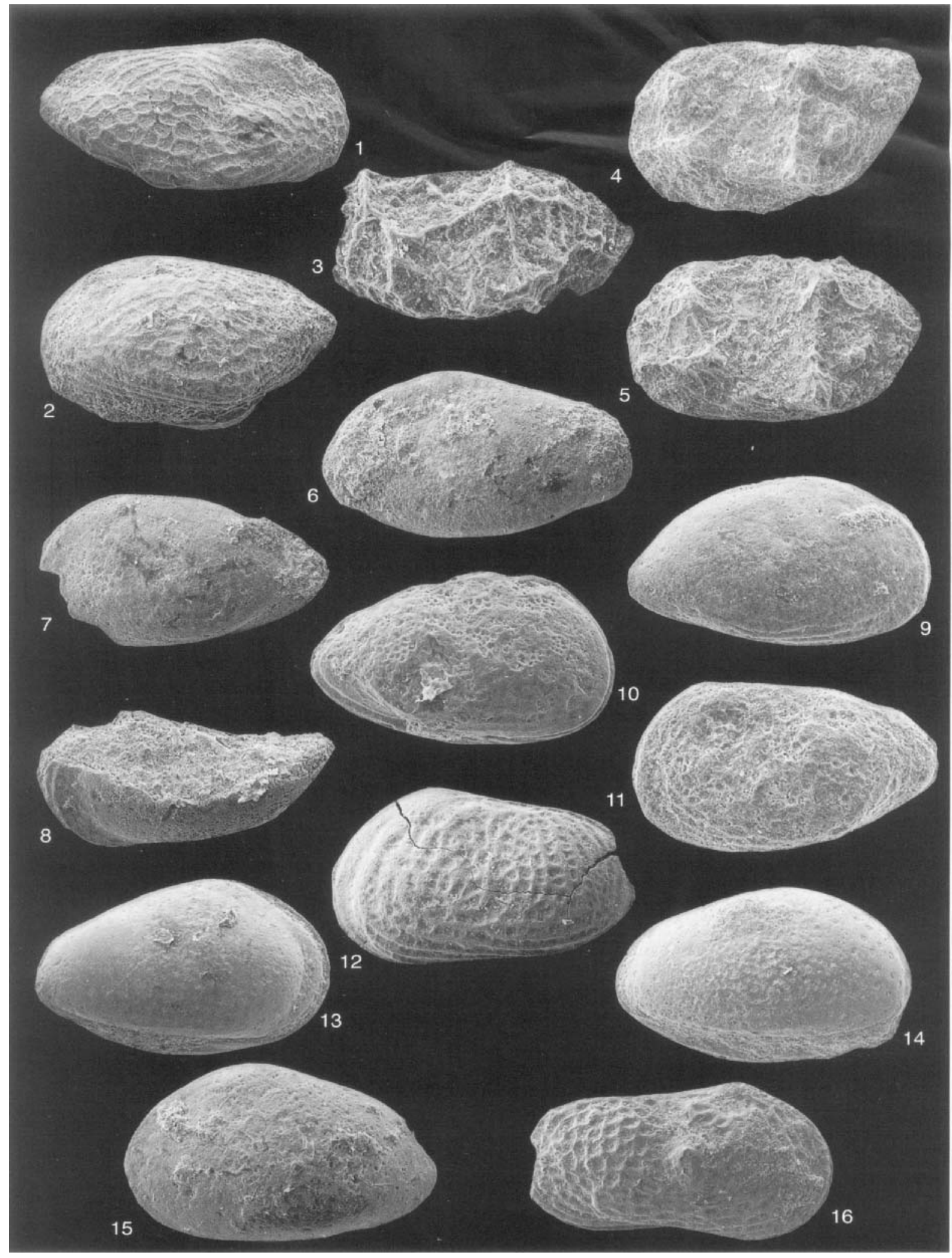


lower part. Pokorny (1973) has also described a form belonging to this group (Lophocythere (Neurocythere) cruciata Triebel, 1951, aff. oxfordiana Lutze, 1960), which shows a similar but somewhat different pattern of ornamentation and cannot be assigned to one of these subspecies or to the southern German specimens. Obviously, this group has undergone a differentiated evolution in the various areas of its distribution. For the classification of the nominate-species into the genus Crucicythere Malz, 1975 see Schudack (1994, pp. 100--101).

\author{
Order Myodocopida Sars, 1866 \\ Suborder Halocypridina Dana, 1852 \\ Superfamily Thaumatocypridacea Müller, 1906 \\ Family Thaumatocyprididae Müller, 1906 \\ Genus Pokornyopsis Kozur, 1974
}

Pokornyopsis feifeli (Triebel, 1941)

$$
\text { (P1. 5, figs 1-3) }
$$

Occurrence. Upper Oxfordian and Lower Kimmeridgian of southern Germany.

Remarks. We follow Kornicker \& Sohn (1976) and Neale (1983), who assign the genus to the subfamily Thaumatocypridacea Müller, 1906. We agree with both authors, who do not see any necessity to deviate from a classification of the genus in the Myodocpoida, as proposed by Kozur (1974). Based upon a detailed study on diverse material, Kornicker \& Sohn (1976) reorientated the valves, so that the two protuberances get into an anteroventral position.

\section{Pokornyopsis punctata n. sp.}

(Pl. 5, figs 4-8)

Derivation of name. After the regularly punctated surface of the valves.

Diagnosis. A species with the characteristics of the genus Pokornyopsis and a lateral surface covered with a network of mostly rounded meshes, which form a regular pattern all over the valves.

Types. Holotype, left valve (Plate 5, fig. 4). Paratypes, 12 specimens. Staatliches Museum für Naturkunde Stuttgart, Inventory-Nr. 75111/1-3.
Locality \& horizon. Schauertal N Streitberg, near Forchheim, northern Franconian Alb, Bavaria, TK 25 sheet 6133 Muggendorf (Fig. 2). Schwamm-Mergel, bimammatum Zone, Upper Oxfordian, Malm beta (Fig. 3).

Description. In lateral view, the valves are roundly-oval in shape, with a straight dorsal, a rounded posterior, and a broadly rounded anterior margin. The antero-dorsal margin is evenly rounded. Two spines occur at approximately midheight and anteroventrally. They can be very long (Plate 5, fig. 6), but are often broken. The upper spine is directed forwards/upwards, whereas the lower spine turns forwards/downwards. Between these spines, the anterior margin is straight or slightly concave. Posterodorsally, there is a third spine, and a slight depression immediately in front of it.

The lateral surface is covered with roundly pentagonal meshes, which are arranged subparallel to the margins and appear to be somewhat disordered centrally over the valves where the central muscle scars are situated. Although the meshes are arranged in rows, there is no impression of striation as the walls of the meshes are equally sized and, thus, optically appear as single elements. The spines are also sculptured. In dorsal view, the carapaces are oval and laterally flattened. The greatest width is situated centrally. Internal features have not been observed in the material.

Dimensions. Length $0.650 .95 \mathrm{~mm}$, height $0.44-0.75 \mathrm{~mm}$.

Occurrence. Upper Oxfordian and Lower Kimmeridgian of southern Germany.

Remarks. The new species differs from the two other species of the genus Pokornyopsis by the regularly punctate pattern of the valve surfaces. In addition, it differs from $P$. feifeli (Triebel, 1941) by the greater distance of the two anterior spines, whereas the upper one turns more upward than in $P$. feifeli (even more than in P. bettenstaedti Bartenstein, 1949). The curvature of the valves is, in comparison to $P$. bettenstaedti, more flattened than in P. feifeli.

\section{CONCLUSIONS}

The data presented here have contributed to a new interpretation of the marine ostracod palaeobiogeography, biostratigra-

\section{Explanation of Plate 3}

Figs 1-2. Eocytheropteron decoratum (Schmidt, 1954), Malm zeta 2b, Upper Solnhofener Schichten, Lower Tithonian, sample Groiss 747, quarry near Unterhartheim: 1, right valve of a male, length $0.52 \mathrm{~mm} ; 2$, right valve of a female, length $0.42 \mathrm{~mm}$. Figs 3-4. Paranotacythere (U.) cf. caputmortuum compactum Bassiouni, 1974, Lower Mörnsheimer Schichten, Lower Tithonian, sample Groiss 37, Oberhartheim near Vohburg/ Donau; 3, left valve, length $0.35 \mathrm{~mm} ; 4$, left valve, length $0.36 \mathrm{~mm}$. Fig. 5. Paranotacythere sp., larval stage ?,Malm alpha, Oxfordian, sample Groiss 452, Feuerstein, left valve, length $0.23 \mathrm{~mm}$; Figs 6-8. Amphicythere (A.) cf. semisulcata Triebel, 1954; 6, Upper Solnhofener Schichten, Lower Tithonian, sample Groiss 60, quarry X. Schöpfel/Hofstetten, south of Pfalzpaint near Eichstätt, left valve, length $0.36 \mathrm{~mm}$; 7, Malm Zeta 2b, Upper Solnhofener Schichten, Lower Tithonian, sample Groiss 728, quarry Imberg near Pfalzpaint east of Eichstätt, left valve, destroyed anteroventrally, length $0.33 \mathrm{~mm} ; 8$, Malm Zeta 2b, Upper Solnhofener Schichten, Lower Tithonian, sample Groiss 60 , quarry X, Schöpfel/Hofstetten south of Pfalzpaint near Eichstätt, left valve, destroyed in its dorsal part, length $0.34 \mathrm{~mm}$; Fig. 9. Hekistocythere lacrimula (Oertli, 1959), Malm Zeta 2b, Upper Solnhofener Schichten, Lower Tithonian, sample Groiss $724 \mathrm{~b}$, quarry X, Schöpfel/Hofstetten south of Pfalzpaint near Eichstätt, right valve, length $0.34 \mathrm{~mm}$; Figs 10-11. Hekistocythere aff. inaequicosta Pokorny, 1973, Malm Zeta 2b, Upper Solnhofener Schichten, Lower Tithonian; 10, sample Groiss 736, quarry near Pfalzpaint, right valve, length $0.31 \mathrm{~mm}$; 11, sample Groiss $724 \mathrm{~b}$, quarry X, Schöpfel/Hofstetten south of Pfalzpaint near Eichstätt, left valve, length $0.29 \mathrm{~mm}$; Fig. 12. Macrodentina (Macrodentina) cf. dolosa Malz, 1958, Lower Mörnsheimer Schichten, Lower Tithonian, sample Groiss 37. Oberhartheim near Vohburg a.d. Donau, left valve, length $0.53 \mathrm{~mm}$; Figs. 13-15. Macrodentina (Macrodentina) punctatula Malz, 1958; 13, Neuburger Bankkalke, Middle Tithonian, sample Groiss 103, quarry Kreut, west of Neuburg a.d. Donau, right valve, length 0.65 mm; 14, Malm Zeta 2b, Upper Solnhofener Schichten, Lower Tithonian, sample Groiss 749, quarry north of Demling, rght valve, length $0.61 \mathrm{~mm}$; 15, Neuburger Bankkalke, Middle Tithonian, sample Groiss 103, quarry Kreut, west of Neuburg a.d. Donau, left valve, length 0.61 mm; Fig. 16, Macrodentina (Macrodentina) sculpta Klingler, 1955, Lower Mörnsheimer Schichten, Lower Tithonian, sample Groiss 37, Oberhartheim near Vohburg a.d. Donau, right valve, length $0.42 \mathrm{~mm}$. 


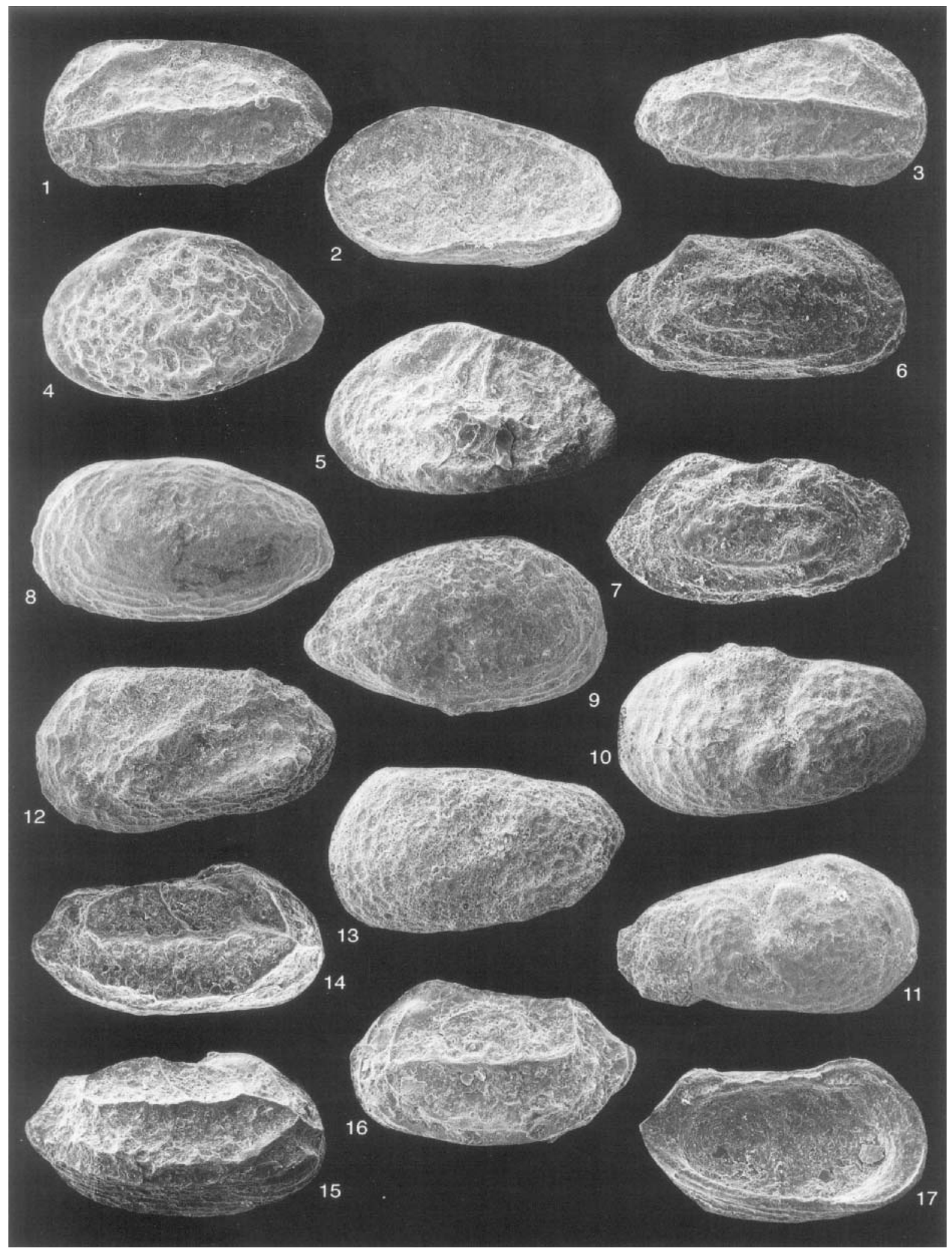


phy, and palaeoclimatology during the late Jurassic in Central and Western Europe (for more details see Schudack \& Schudack (1997) and Schudack (1999)).

The palaeobiogeographical development parallels a postulated cooling trend. During the Oxfordian, Kimmeridgian, Tithonian and Berriasian, a growing diversification of marine ostracod biogeography and an increase in the degree of endemism can be observed. In addition, there is a gradual southward migration of many species from the sub-boreal areas in the northwest towards the margin of the Tethys in the southeast, mainly from the Kimmeridgian into the Tithonian. For instance, most species occurring both in northern and southern Germany have been reported to appear (and also disappear) in younger strata in the south (Schudack \& Schudack, 1997). Moreover, the genus Cytherelloidea, an indicator for relatively warm water temperatures, shifts its northern boundary of occurrence towards the south during the Kimmeridgian, Tithonian and Berriasian (Schudack, 1999). These data are in agreement with a suggested increase in the influx of cold boreal waters into Central Europe with the beginning of the Tithonian, leading to slightly colder water temperatures in the shallow seas, reduced atmospheric moisture, cool-arid conditions on the neighbouring continents, and also to the diversification of biogeographic regions as a reaction to the conflicting boreal (increased) and Tethyan (constant) influences.

Different stratigraphical ranges of most taxa in northern and southern Germany hinder ostracod-based correlations between these two areas.

\section{ACKNOWLEDGEMENTS}

The authors wish to thank Prof. Groiss (Erlangen), Dr Schairer (Munich) and Dr Urlichs (Stuttgart), who kindly made the major part of the material for this investigation available. The 'Deutsche Forschungsgemeinschaft' (Bonn) supported the research of U. Schudack by a 'Forschungsstipendium'.

\section{Manuscript received November 1997 Manuscript accepted September 2000}

\section{REFERENCES}

Alexander, C. I. 1929. Ostracoda of the Cretaceous of North Texas. University of Texas Bulletin, 2907: 2-137.

Baird, W. 1850. The natural history of the British Entomostraca. Ray Society, London.

Bartenstein, H. 1949. Thaumatocypris bettenstaedti, n. sp., aus dem nordwestdeutschen Lias zeta (Ostrac.). Senckenbergiana, 30(1/3): 95 98.

Bassiouni, M. A. A. 1974. Paranotacythere n. gen. (Ostracoda) aus dem Zeitraum Oberjura bis Unterkreide (Kimmeridgium bis Albium) von Westeuropa. Geologisches Jahrbuch, A 17: 3-111.

Bate, R. H. 1969. Some Bathonian ostracoda of England with a revision of the Jones 1884 and Jones \& Sherborn 1888 collections. Bulletin of the British Museum (Natural History), Geology, 17(8): 377-437.

Bate, R. H. 1975. Ostracods from Callovian to Tithonian sediments of Tanzania, East Africa. Bulletin of the British Museum (Natural History), Geology, 26(5): 161-223.

Bizon, J.-J. 1958. Foraminifères et ostracodes de l'Oxfordien de Villerssur-mer (Calvados). Revue de l'Institut Francais du Pétrole, 13: 3-45.

Dana, J. D. 1852. Crustacea: Cyproidea. United States Exploring Expedition during the years 1838-1842 under the command of Charles Wilkes, 13(2): 1277-1304.

Depèche, F. 1985. Lias supérieur, Dogger, Malm. $n$ Oertli, H.J. (Ed.), Atlas des ostracodes de France, Of-Aquitain, Pau. 119-145.

Dietl, G. \& Schweigert, G. 1995. Jahrestagung in Beuron, Obere Donau (24.5.-27.5.1995). Excursion Guide for DUGW-Stratigraphical Commission, Subcommission on Jurassic Stratigraphy. DUGW-Stratigraphische Kommission, Stuttgart.

Donze, P. 1960. Les formations du Jurassique terminal dans la partie nordouest de l'Isle d' Oleron (Charente Maritime). Travaux de la Laboratoire de Géologie Lyon (nouvelle série), 5: 5-30.

Glashoff, H. 1964. Ostrakoden-Faunen und Paläogeographie im Oxford NW-Europas. Paläontologische Zeitschrift, 38: 28-65.

Gründel, J. 1964. Neue Ostracoden aus der deutschen Unterkreide. Monatsberichte der Deutschen Akademie der Wissenschaften Berlin, 6(11): 849-858.

Gründel, J. 1974a. Zur Entwicklung der Trachyleberididae (Ostracoda) in der Unterkreide und in der tiefen Oberkreide. Teil II: Phylogenie. Zeitschrift für geologische Wissenschaften Berlin, 1974(1): 61-71.

Gründel, J. 1974b. Zur Taxionomie und Phylogenie der Cytherettidae Triebel 1952 (Ostracoda, Crustacea). Freiberger Forschungshefte C 298: $81-99$.

Gründel, J. 1975. Zur Entwicklung der Trachyleberididae (Ostracoda) im Jura. Zeitschrift für geologische Wissenschaften Berlint, 1975(3): 363-374.

Gründel, J. \& Kozur, H. 1972. Zur Taxionomie der Bythocytheridae und Tricorninidae (Podocopida, Ostracoda). Monatsberichte der Deutschen Akademie der Wissenschaften Berlin, 13 (1971) (10/12): 907-937.

\section{Explanation of Plate 4}

Figs 1-3. Palaeocytheridea groissi Schudack, 1997, Lower Mörnsheimer Schichten, Lower Tithonian, sample Groiss 37, Oberhartheim near Vohburg/ Donau: 1, left valve, length $0.4 \mathrm{~mm} ; \mathbf{2}$, right valve from inside, length $0.39 \mathrm{~mm} ; \mathbf{3}$, right valve from inside, length $0.39 \mathrm{~mm}$; Figs 4-5. Procytheridea gublerae Bizon, 1958; 4, lamberti Zone, henrici Subzone, uppermost Callovian, Kandern, leg, Dietl 1967, left valve, length $0.54 \mathrm{~mm}$, inventory-Nr. 75120 Staatliches Museum für Naturkunde Stuttgart; 5, Malm alpha, Oxfordian, sample Groiss 376, Unterklausen 3, 131.25-131.55 m, left valve, length $0.55 \mathrm{~mm}$. Figs 6-7. Quasihermanites spiralus n. sp. Hattinger Trümmerkalke, Upper Kimmeridgian, Talmühle, $2 \mathrm{~km}$ north of Engen, railway cutting on the Tuttlingen/Singen line; 6, sample SD 24, right valve, length $0.46 \mathrm{~mm}$; , holotype, sample SD 22, right valve, length $0.46 \mathrm{~mm}$, inventory Nr. MT 1997-1 Institut für Paläontologie FU Berlin. Figs 8-9. Rectocythere (Rectocythere) iuglandiformis (Klingler, 1955), Mörnsheimer Schichten, Lower Tithonian; 8, sample Groiss 10, Untermöckernlohe 1005, 19.25-19.39 m, left valve, length 0.46 mm; 9, sample Groiss 12 , Untermöckernlohe 1005, 20.79-20.85 m, right valve, length 0.54 mm. Figs 10-11. Rectocythere (Rectocythere) nanus Pokorny, 1973, Malm zeta 3, Lower Mörnsheimer Schichten, Lower Tithonian; 10, sample Groiss 730, quarry Imberg near Pfalzpaint, left valve, length 0.40 mm; 11, sample Groiss 733 , quarry X, schöpfel/Hofstetten south of Pfalzpaint near Eichstätt, left valve, length $0.40 \mathrm{~mm}$. Figs 12-13. Rectocythere (Lydicythere) rugosa Malz, 1966; 12, Lower Tithonian, sample Groiss 60, quarry X. Schöpfel/Hofstetten south of Pfalzpaint near Eichstätt, left valve, length $0.36 \mathrm{~mm}$; 13, Malm zeta 3, Lower Mörnsheimer Schichten, Lower Tithonian, sample Groiss 730, right valve, length $0.36 \mathrm{~mm}$. Figs 14-17. Crucicythere gr. cruciata (Triebel, 1951); 14, Malm alpha, Oxfordian, sample Groiss 376, Unterklausen 3, 131.25-131.75 m, right valve, length $0.51 \mathrm{~mm}$; 15, lamberti Zone, henrici Subzone, uppermost Callovian, Kandern, leg, Dietl 1967, right valve, length $0.57 \mathrm{~mm}$, inventory-Nr. 75119/1 Staatliches Museum für Naturkunde Stuttgart; 16-17. Malm alpha, Oxfordian, sample Groiss 377, Unterklausen 3, 131.25-131.75 m; 16, left valve, length $0.58 \mathrm{~mm}$; 17, left valve from inside, length $0.50 \mathrm{~mm}$. 


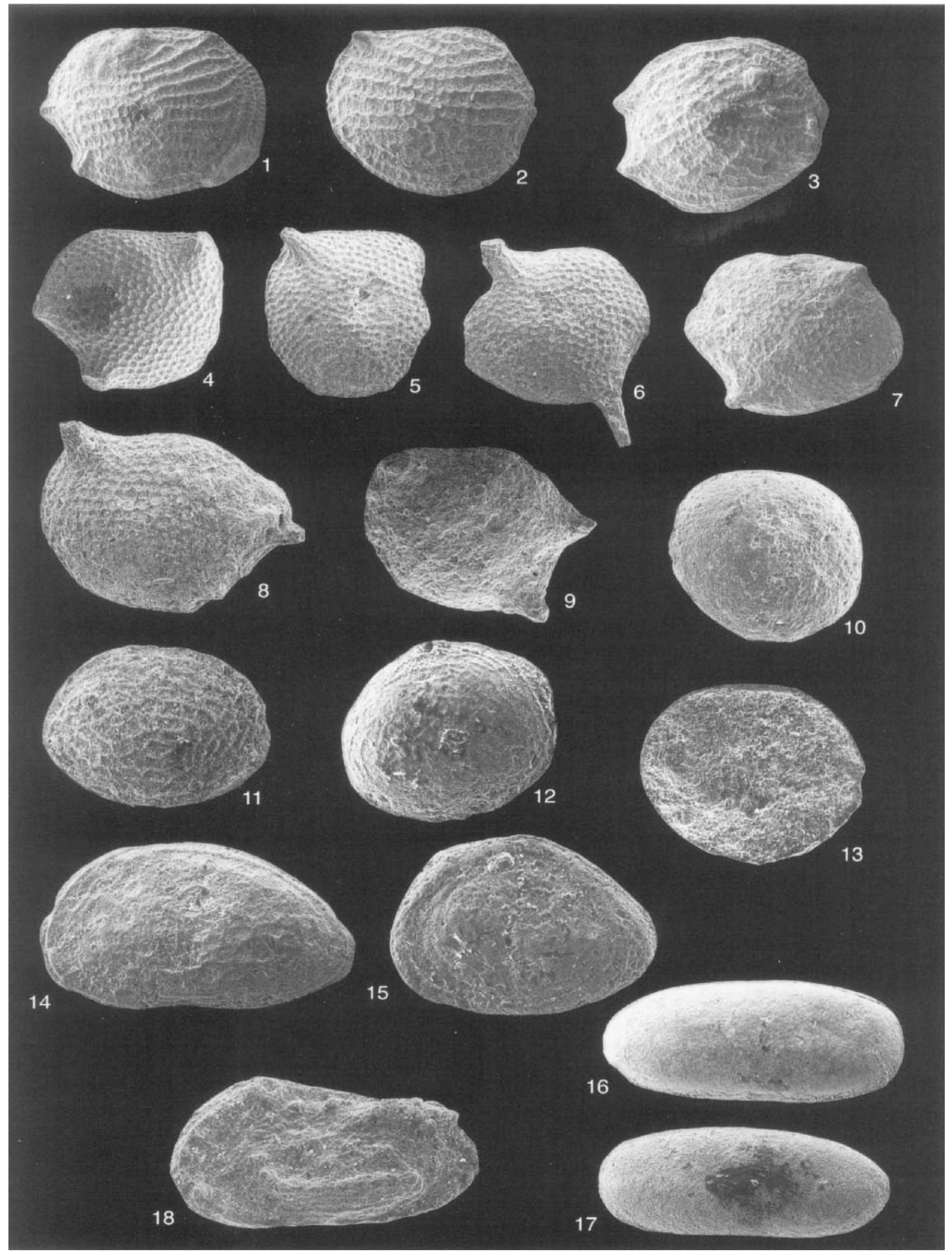


Hornibrook, N. de B. 1952. Tertiary and recent marine Ostracoda of New Zealand. Their origin, affinities, and distribution. Palacontological Bulletins, New Zealand Geological Survey, 18: 1-82.

Kaye, P. 1965. Ranocythereis, a new ostracod genus from the British Lower Cretaceous. Senckenbergiana lethaea, 46(1): 83-87.

Klingler, W. 1955. Mikrofaunistische und stratigraphisch-fazielle Untersuchungen im Kimmeridge und Portland des Weser-Aller Gebietes. Geologisches Jahrbuch, 70: 167-246.

Kornicker, L. S. \& Sohn, I. G. 1976. Phylogeny, Ontogeny, and Morphology of Living and Fossil Thaumatocypridacea (Myodocopa:Ostracoda). Smithsonian Contributions to Zoology, 219: 1-124.

Kozur, H. 1971. Beiträge zur Ostracodenfauna der tethyalen Trias, Teil 2: Neue Ostracodenarten aus der tethyalen Trias. Geologischpaläontologische Mitteilungen Innsbruck, 1(2): 14-68.

Kozur, H. 1974. Eine neue Gattung der Familie Polycopidae (Cladocopida, Ostracoda). Zeitschrift für geologische Wissenschaften Berlin, 2(7): 853-855.

Ljubimova, P. S. 1955. Ostrakody mesozojskich otlozenij srednego Povolzja i Obscego Syrta. Trudy VNIGRI, N.S., 84: 3-190.

Lord, A. R., Cooper, M. K. E. , Corbett, P. W., Fuller, N. G., Rawson, P. F. \& Rees, A. J. J. 1987. Microbiostratigraphy of the Volgian Stage (Upper Jurassic), Volga River, U.S.S.R. Neues Jahrbuch für Geologie und Paläontologie, Monatshefte, 1987(10): 577-605.

Lutze, G. 1960. Zur Stratigraphie und Paläontologie des Callovien und Oxfordien in Nordwestdeutschland. Geologisches Jahrbuch, 77: 391532.

Malz, H. 1958. Die Gattung Macrodentina und einige andere Ostracodenarten aus dem Oberjura von NW-Deutschland, England und Frankreich. Abhandlungen der senckenbergischen naturforschenden Gesellschaft, 497:1-67.

Malz, H. 1966. Rectocythere rugosa, eine neue Ostracoden-Art aus dem französischen Portlandien. Senckenbergiana lethuea, 47(4): 405-409.

Malz, H. 1975. Die Arten der Gattung Lophocythere, ihre stratigraphische und regionale Verbreitung. Senckenbergiana lethaea, 56(2/3): 123-145.

Meyer, K. F. \& Schmidt-Kaler, H. 1996. Jura. In Erläuterungen zur Geologischen Karte von Bayern 1: 500000, 90-109.

Müller, G. W. 1894. Die Ostracoden des Golfes von Neapel und der angrenzenden Meeresabschnitte. Fauna und Flora des Golfes von Neapel und der angrenzenden Meeresabschnitte (Zoologische Station zu Neapel), 21: 1-404.

Müller, G. W. 1906. Ostracoda. In Wissenschaftliche Ergebnisse der deutschen Tiefsee-Expedition 1898-99, 8(2): 1-154.

Neale, J. W. 1983. Geological History of the Cladocopina. In Maddocks, R. F. (Ed.), Applications of Ostracoda. Proceedings of the 8th
International Symposium on Ostracoda, Houston 1982, 612-626. University of Houston, Texas.

Oertli, H. J. 1957. Ostracodes du Jurassique supérieur du Bassin de Paris (Sondage Vernon 1). Revue de l'Institut Francais du Pétrole, 12(6): 647-695.

Oertli, H. J. 1959. Malm-Ostrakoden aus dem schweizerischen Juragebirge. Mémoires de la Société Helvétienne des Sciences Naturelles, 83(1): 1-44.

Oertli, H. J. 1963. Faunes d'ostracodes du Mésozoique de France. Brill, Leiden.

Oertli, H. J. 1965. Ostrakoden der Neuburger Bankkalke (Mittleres Tithon) von Neuburg an der Donau, Südbayern. Mitteilungen der Bayrischen Staatssammlung für Paläontologie und Historische Geologie, 5: 127-135.

Pokorny, V. 1973. The Ostracoda of the Klentnice formation (Tithonian ?), Czechoslovakia. Acad. naklad. Ces. Akad. ved., 40: 1-107.

Rosenfeld, A., Gerry, E. \& Honigstein, A. 1987. Jurassic Ostracodes from Gebel Maghara, Sinai, Egypt. Revista Española de Micropaleontologia, 19: 251-280.

Sars, G. O. 1866. Oversigt af Norges Marine Ostracoder. Forhandelingen i Videnskabs-Selskabet I Christiania, 1865: 1-130.

Sars, G. O. 1926. An account of the Crustacea of Norway with short descriptions and figures of all the species. Vol.9 (Ostracoda), 13-14: 209-240. Bergen Museum.

Schmidt, G. 1954. Stratigraphisch wichtige Ostracoden im Kimmeridge und tiefsten 'Portland' NW-Deutschlands. Paläontologische Zeitschrift, 28(1/2): 81-101.

Schudack, M. 1999. Ostracoda (marine/nonmarine) and paleoclimate history in the late Jurassic of Central Europe and North America. Marine Micropaleontology, 37: 273-288.

Schudack, M. \& Schudack, U. 1997. Biostratigraphische und biogeographische Beziehungen der süddeutschen Oberjura-Ostracoden: Parallelen zu paläogeographischen und paläoklimatischen Entwicklungen. Geologische Blätter NO-Bayern, 47: 99-116.

Schudack, U. 1994. Revision, Dokumentation und Stratigraphie der Ostracoden des nordwestdeutschen Oberjura und Unter-Berriasium. Berliner geowissenschaftliche Abhandiungen, E 11: 1-193.

Schudack, U. 1997. Palaeocytheridea groissi n. sp. (Ostracoda) aus den Mörnsheimer Schichten (Tithonium) von Oberhartheim bei Vohburg (Donau). Geologische Blätter NO-Bayern, 47: 17-24.

Schweigert, G. \& Callomon, J. H. 1997. Der bauhini-Faunenhorizont und seine Bedeutung für die Korrelation zwischen tethyalem und subborealem Oberjura. Stuttgarter Beiträge zur Naturkunde, B 247: 169.

Steghaus, H. 1951. Ostracoden als Leitfossilien im Kimmeridge der

\section{Explanation of Plate 5}

Figs 1-3. Pokornyopsis feifeli (Triebel, 1941), Schwamm-Mergel, bimammatum Zone Upper Oxfordian, Schauertal near Streitberg near Forchheim (Oberfranken): 1, left valve, length $0.95 \mathrm{~mm}$, inventory-Nr. $75110 / 2$ Staatliches Museum für Naturkunde Stuttgart; 2, right valve of a larval stage, length $0.65 \mathrm{~mm}$, inventory-Nr. 75110/1 Staatliches Museum für Naturkunde Stuttgart; 3, left valve, length $1.14 \mathrm{~mm}$, inventory-Nr. $75110 / 3$ Staatliches Museum für Naturkunde Stuttgart. Figs 4-8. Pokornyopsis punctata n. sp: 4-7. Schwamm-Mergel, bimammatum Zone, Upper Oxfordian, Schauertal near Streitberg, near Forchheim (Oberfranken); 4, left valve, length $0.60 \mathrm{~mm}$, inventory-Nr. 75I 11/2 Staatliches Museum für Naturkunde Stuttgart; 5, right valve, anterior margin destroyed, length $0.75 \mathrm{~mm}$, inventory- $\mathrm{Nr}$. 75102 Staatliches Museum für Naturkunde Stuttgart; 6, right valve, anterior margin destroyed, length $0.87 \mathrm{~mm}$, inventory-Nr. $75111 / 3$ Staatliches Museum für Naturkunde Stuttgart; 7, holotype, left valve, length $0.93 \mathrm{~mm}$, inventory-Nr. 75111/1 Staatliches Museum für Naturkunde Stuttgart; 8, Malm delta, Kimmeridgian, sample Groiss 166. Attendorfer Steige, SE Lichtenfels, right valve, anterior margin destroyed, length $0.5 \mathrm{~mm}$ (without spine). Fig. 9. Pokornyopsis sp. Schwamm-Mergel, bimammatum Zone, Upper Oxfordian, Schauertal near Streitberg,near Forchheim (Oberfranken), right valve, length $0.51 \mathrm{~mm}$, inventory-Nr. 75112 Staatliches Museum für Naturkunde Stuttgart. Figs 10-13. Polycope sububiquita Whatley, 1970; 10, platynota or hypselocyclum Zone, Lower Kimmeridgian, Auendorf, Coll. K. Feifel, 1947, right valve, length $0.44 \mathrm{~mm}$, inventory-Nr. 75104/1 Staatliches Museum für Naturkunde Stuttgart; 11, Polycope sububiquita Whatley, 1970, Malm gamma, Kimmeridgian, sample Groiss 183, Dornig, SE Staffelstein, right valve, length 0.32 mm; 12, bifurcaius Zone, Upper Oxfordian, Reichenbach im Täle, Coll. K. Feifel, 1947, left valve, length $0.32 \mathrm{~mm}$, inventory-Nr. 75118/1 Staatliches Museum für Naturkunde Stuttgart; 13, Malm delta, Kimmeridgian, sample Groiss 135, NW Dörnwasserlos, S Lichtenfels, right valve from inside, length $0.33 \mathrm{~mm}$. Fig. 14. gen. et sp. indet A. Malm zeta 2b, Upper Solnhofener Schichten, Lower Tithonian, sample Groiss 747, quarry near Unterhartheim, left valve, length $0.44 \mathrm{~mm}$. Fig. 15. gen. et sp. indet B, Larve? Malm delta, Kimmeridgian, sample Groiss 138, Oberküps, S Lichtenfels, left valve, length $0.35 \mathrm{~mm}$. Figs 16-17, gen. et sp. indet C aff. Indet gen. et sp. Oertli, 1959. Bifurcatus Zone, Upper Oxfordian, Crest at Irrenberg near Balingen, leg, Urlichs $1.5 .67 ; 16$, left valve, length $0.54 \mathrm{~mm} ; 17$, right valve, length $0.62 \mathrm{~mm}$, inventory-Nr. $75109 / 1$ Staatliches Museum für Naturkunde Stuttgart. Fig. 18. gen. et sp. indet D ? ex gr. 'Protocythere', Hattinger Trümmerkalke, Upper Kimmeridgian, sample: SD 27, Talmühle, 2 km north of Engen, railway cutting in the Tuttlingen/Singen line, left valve, length $0.50 \mathrm{~mm}$. 
Ölfelder Wietze und Fuhrberg bei Hannover. Paläontologische Zeitschrift, 24(3/4): 201-224.

Swain, F. M. \& Anderson, E. G. 1993. Stratigraphy and Ostracoda of the Cotton Valley Group Northern Coastal Region. Geological Bulletin, 45: 1-241.

Sylvester-Bradley, P. C. 1948. Bathonian Ostracoda from the Boueti Bed of Langton Herring, Dorset. Geological Magazine, 85: 185-204.

Triebel, E. 1941. Zur Morphologie und Ökologie der fossilen Ostracoden. Senckenbergiana, 23(1/6): 294-400.

Triebel, E. 1951. Einige stratigraphisch wertvolle Ostracoden aus dem höheren Dogger Deutschlands. Abhandlungen der senckenbergischen naturforschenden Gesellschaft, 485: 87-102.

Triebel, E. 1952. Ostracoden der Gattung Cytheretta aus dem Tertiär des Mainzer Beckens. Notizblatt des hessischen Landesamtes für Bodenforschung, Serie 6, 3: 15-30.

Triebel, E. 1954. Malm-Ostracoden mit amphidontem Schloß. Senckenbergiana lethaea, 35(1/2): 3-16.

Triebel, E. \& Bartenstein, H. (1938): Ostracoden des deutschen Juras. 1. Monoceratina-Arten aus dem Lias und Dogger. Senckenbergiana, 20: $502-518$.
Weiss, M. 1995. Stratigraphie und Microfauna im Kimmeridge SENiedersachsens unter besonderer Berücksichtigung der Ostracoden. Clausthaler Geowissenschaftliche Dissertationen, 48: 1-274.

Whatley, R. C. 1970. Scottish Callovian and Oxfordian Ostracoda. Bulletin of the British Museum (Natural History), Geology, 19(6): 297358

Witte, L. \& Lissenberg, T. 1994. Late Jurassic and Ryazanian ostracod faunas from the Dutch Central Graben. Mededelingen van de Rijks Geologische Dienst, 51: 1-69.

Zeiss, A. 1977. Jurassic stratigraphy of Franconia. Stuttgarter Beiträge zur Naturkunde, B 31: 1-32.

Ziegler, B. 1977. The 'White' (Upper) Jurassic in Southern Germany. Stuttgarter Beiträge zur Naturkunde, B 26: 1-79.

Ziegler, P. A. 1990. Geological atlas of Western and Central Europe. (2nd edition) Shell Internationale Maatschappij BV, Den Haag.

Zihrul, B. 1990. Mikrobiostratigraphie, Palökologie und Mikropaläontologie in Gesteinen des Unteren und Mittleren Malm am Langenberg bei Goslar/Oker. Clausthaler Geowissenschaftliche Dissertationen, 38: $1-220$. 